\title{
Description of the Movement of a Tompion Clock presented to The Institution of Civil Engineers in 1847 by Benjamin Lewis Vulliamy, Assoc. Inst. C.E.
}

Thrs movement, which was stated by the donor to belong to a clock presented by King Charles II to Barbara Villiers, Duchess of Cleveland, possesses many features of special interest. Its maker; Thomas Tompion, who has been rightly called "the father of English clock-making," was born.at Northill, Bedfordshire, in 1638, and on his death in November, 1713, he was buried in Westminster Abbey. He carried on business for many years in Water Lane, Blackfriars, and was the leading clock-maker at the Court of Charles II. He studied and turned to practical account the inventions of Dr. Hooke and the Rev. Edward Barlow relating to time-keeping, and as a result effected considerable progress in the art of clock- and watch-making. George Graham, who subsequently did so much for English clock-making, and who was the inventor of the dead-beat escapement and the mercurial pendulum, was his favourite pupil.

The clock-movement presented to The Institution is a remarkable example of high finish and accurate workmanship, particularly when the character of the lathes and tools available at the time of its construction is taken into account. The clock was stated by Vulliamy to have been constructed about the year 1670, when Tompion would be about 32 years of age. The parts presented to The Institution consisted of the movement only, without dial or hands, and it remained in this condition until 1913, when, at the suggestion of Dr. William H. Maw, M. Inst. C.E., to whom The Institution is indebted for its renovation, and this account of it, it was placed in the hands of Mr. E. T. Cottingham, of Thrapston, Northamptonshire, in order that it might be restored to going condition. To enable this to be done, the movement was supplied with a skeleton dial and with hands, while the whole was placed in a glass case, so that all the parts are visible for inspection. The following particulars of the special features of the clock have been prepared from notes supplied by Mr. Cottingham. 
The clock goes for 8 days and is driven by the usual spring and fusee through a catgut line, and it is fitted with a verge escapement of the kind in general use in bracket clocks at the time of its construction. The axle of the escape-wheel is vertical and is driven by a wheel at right angles to it, having contrate teeth. In this form of escapement, the pallets work across the diameter of the escape-wheel, and this means that the latter, in order to escape, must always have an odd number of teeth. The pallets were usually made of hardened steel (at a later date some of them were jewelled), but in the clock under notice they are replaced by two brass arms, between which is stretched a thin string of catgut, upon which the teeth of the escape-wheel act. This arrangement presents a remarkable contrast to the use of hardened steel pallets, the surfaces of which are frequently pitted, owing to the impact of the wheel-teeth, and it affords further evidence of the wearing qualities of a soft substance when suitably associated with a hard one.

The striking mechanism is somewhat complicated, and is quite unusual in its construction. The ordinary practice in clocks of this kind is to provide a separate train of wheels for each function of going, striking, and chiming, but in this clock, by the employment of an ingenious system of levers, one train does the double duty of striking the hours and chiming the quarters, either at every quarter, or repeating them at will by the pulling of a cord attached to the springy levers at the side of the movement. The hours and quarters are not released by the two-stage method of "warning" a few minutes before the time, but are released, without warning, at the moment of striking. This method has been adopted in recent years in the best French carriage-clocks; otherwise they cannot be made to repeat during the warning period. The clock is also fitted with an alarm, which is set from a centre dial behind the hour hand, this dial controlling the alarm train, the motive power of which is the deflection of a radial spring. This spring has a toothed segment gearing into a pinioned ratchet, which deflects the spring when wound. The silent beat given by the catgut pallets already described and the existence of an alarm in the same clock suggest that it was specially designed as a bedroom clock.

There is a hand on the left-hand side of the dial for regulating the time, and a similar one on the right for winding the alarm. Below these, at the base of the clock, are two similar hands, which, when moved one quarter of a turn inwards, actuate two forked levers which clip the pendulum when it is required to move the clock.

Without Vulliamy's authentic evidence of its history, or the dial which would bear 'Tompion's name, there is ample proof, to those 
accustomed to Tompion's style, that he was the maker of this clock, and a note on Vulliamy's practice will doubtless throw some light upon the presentation to 'The Institution of the movement only. Benjamin Lewis Vulliamy ${ }^{1}$ was the last of three generations of Court clock-makers, and was famous for the fine finish he gave to the prevailing practice of his day, rather than for any new departures in design. He had no desire for keeping the combinations of even renowned makers intact if their clocks needed rather more care than his own, and quite a number of noted clocks by other makers can be found fitted with Vulliamy's movements. This, Mr. Cottingham considers, is the probable channel through which this historic movement by Tompion passed into the hands of its donor to The Institution, and it may be that its original case, dial, and hands are still in existence, dealing out time from a movement of later construction.

1 See Memoir, Minutes of Proceedings Inst. C.E., vol. xiv, p. 155. 